\title{
Bioedusiana
}

http://jurnal.unsil.ac.id/index.php/bioed

DOI: https://doi.org/10.37058/bioed.v6i2.2547

Bioedusiana

\section{Video dan Google Classroom: Sebuah Cara untuk Meningkatkan Motivasi Belajar Biologi Siswa SMAN 1 Pagaran Tapah, Riau}

\section{Video and Google Classroom: A Way to Increase Biology Learning Motivation for Students at SMAN 1 Pagaran Tapah, Riau Province}

\author{
Suri Yustini ${ }^{1 *}$, Restesa Rahmayumita ${ }^{2}$, Nurkhairo Hidayati ${ }^{3}$ \\ ${ }^{1}$ SMAN 1 Pagaran Tapah Darussalam, Rukan Hulu, Riau, 28556 \\ ${ }^{2,3}$ Universitas Islam Riau, Pekanbaru, Riau, 28284
}

\begin{abstract}
Abstrak
Motivasi merupakan salah satu faktor penting dalam proses pembelajaran. Penelitian ini bertujuan untuk mengetahui motivasi belajar biologi siswa dengan menggunakan media berbasis video melalui penggunaan Google Classroom. Penelitian ini menggunakan metode deskriptif dengan teknik survei pada siswa kelas XI IPA SMAN 1 Pagaran Tapah Darussalam Tahun Ajaran 2020/2021. Sampel penelitian adalah seluruh siswa kelas XI IPA yang berjumlah 30 orang. Instrumen yang digunakan berupa angket motivasi yang terdiri dari $35 \mathrm{item}$. Teknik pengumpulan data menggunakan angket online yang dibuat melalui Google Form. Hasil penelitian menunjukkan rata-rata motivasi belajar siswa 75,65\% yang berada pada kategori tinggi. Indikator tertinggi yaitu perasaan senang sedangkan yang paling rendah adalah efektifitas media. Kesimpulan yang diperoleh dari hasil penelitian ini bahwa penggunaan video pembelajaran melalui Google Classroom dapat meningkatkan motivasi belajar biologi siswa di kelas XI IPA SMAN 1 Pagaran Tapah Darussalam. Mengacu pada hal ini, guru-guru di sekolah dapat memanfaatkan video selama proses belajar mengajar yang dikombinasikan Google Classrom sehingga motivasi belajar siswa dapat mengalami peningkatan.
\end{abstract}

Kata kunci: Motivasi Belajar; Media Video; Google Classroom.

\begin{abstract}
Motivation is an important factor in the learning process. This study aims to determine students' motivation to learn biology by using video-based media using google classroom. This study used a descriptive method with survey techniques for class XI IPA students of SMAN 1 Pagaran Tapah Darussalam in the academic year 2020/2021. The research sample was all students of class XI IPA, amounting to 30 people. The instrument used was a motivation questionnaire consisting of 35 items. The data collection technique uses an online questionnaire created via google form. Based on the results of data analysis, it was found that the student's learning motivation was 75,65\% in the high category. The highest indicator is feeling happy while the lowest is the effectiveness of the media. The conclusion obtained from the results of this study is that the use of video lessons through google classroom can increase the motivation to learn biology of students in class XI IPA SMAN 1 Pagaran Tapah Darussalam. Referring to this, teachers in schools can use video as a learning medium to increase student motivation.
\end{abstract}

Keywords: Learning Motivation; Video Media; Google Classroom.

Article History

Received: January $13^{\text {th }}, 2021$;Accepted: November $19^{\text {th }}, 2021$;Published: December $31^{\text {st }}, 2021$

Corresponding Author*

Nurkhairo Hidayati, Program Studi Pendidikan Biologi FKIP Universitas Islam Riau, E-mail: khairobio@edu.uir.ac.id (C) 2021 Bioedusiana. This is an open access article under the CC BY-SA 4.0 license (https://creativecommons.org/licenses/by-sa/4.0/)

\section{PENDAHULUAN}

Belajar tidak selalu berisi definisi tentang materi pelajaran karena di dalamnya terlibat banyak aspek. Pengertian belajar Istilah belajar menjadi topik yang paling banyak dipelajari dalam psikologi sehingga banyak juga ahli yang telah mendefinisikan istilah ini (Houwer, Barnes-Holmes \& Moors, 2013). Belajar melibatkan hubungan stimulus dan respon yang 
dikembangkan sebagai konsekuensi dari interaksi lingkungan fungsional melalui indera (Qvortrup, Wiberg, Christensen \& Hansbøl, 2016). Belajar dapat dipahami sebagai tahap perubahan tingkah laku yang diperoleh melalui pengalaman sehingga bisa tertanam pada diri seseorang dalam kapasitas untuk berperilaku dengan cara tertentu (Schunk, 2012). Salah satu upaya mencapai perubahan tingkah laku dibutuhkan motivasi. Motivasi juga dapat mempengaruhi proses belajar siswa (Tsai, Cheng, Yeh \& Lin, 2016).

Motivasi belajar merupakan daya penggerak dari dalam dan dari luar diri siswa dengan memberikan arahan untuk kegiatan belajar hingga terwujudnya proses pembelajaran yang diinginkan (Lubis, 2016). Menurut Emda (2017), motivasi merupakan salah satu faktor pendorong keinginan siswa untuk belajar. Adanya motivasi belajar sangat mempengaruhi keberhasilan siswa. Jika dalam diri siswa masih ada kemauan dan dorongan belajar maka keberhasilan belajar akan tercapai. Sejalan dengan itu Saptono (2016) menyatakan bahwa motivasi secara langsung maupun tidak langsung akan mempengaruhi hasil belajar siswa. Motivasi belajar juga dapat didefinisikan sebagai pengubahan kekuatan pada seseorang dengan menggunakan dorongan secara internal maupun eksternal untuk mengarakan tindakan yang pada akhirnya mengarah pada perubahan perilaku dan aktivitas belajar. Aktivitas belajar pada jenjang pendidikan menengah berlangsung pada berbagai mata pelajaran, misalnya biologi (Umairah \& Zulfah, 2020).

Biologi merupakan salah satu mata pelajaran yang sifatnya kompleks karena berkaitan dengan kehidupan dan makhluk hidup. Pembelajaran biologi membutuhkan berbagai keterampilan pemrosesan lisan dan tertulis, yang diharapkan dapat menghasilkan kemampuan kognitif, psikomotor, dan afektif yang baik (Nafisah, 2011; Simorangkir \& Napitupulu, 2020). Materi abstrak sering dijumpai dalam proses pembelajaran biologi yang sedang berlangsung, sehingga materi tersebut menjadi sulit untuk dipahami oleh siswa. Hal inilah yang menjadi penyebab rendahnya motivasi siswa, terutama ketika guru menggunakan metode ceramah yang seringkali sangat membosankan (Listiyanto, 2015).

Keberadaan media pembelajaran merupakan bagian penting dalam proses pembelajaran dan dapat memotivasi siswa untuk belajar. Secara umum media pembelajaran merupakan alat bantu proses belajar mengajar yang dapat digunakan untuk merangsang pemikiran, perasaan, perhatian, kemampuan atau keterampilan siswa, sehingga memudahkan dalam proses pembelajaran (Listiyanto, 2015). Lebih lanjut Syahbani, Haris \& Palloan (2019) memaparkan bahwa pendidik diharapkan mampu menyesuaikan media pembelajaran dengan tujuan pembelajaran yang ingin dicapai.

Media pembelajaran mencakup banyak jenis salah satunya adalah video. Video merupakan media audio visual dengan elemen suara dan gambar. Penggunaan media video dalam pembelajaran dapat secara efektif mengatasi keterbatasan jarak dan waktu, pesan yang 
disampaikan lebih mudah dan singkat, serta dapat mengembangkan pikiran dan wawasan siswa. Video pembelajaran sangat cocok untuk pembelajaran biologi karena terlalu banyak proses kehidupan yang tidak dapat dijelaskan secara nyata. Oleh karena itu pendidik membutuhkan media atau alat bantu untuk mendeskripsikannya kepada siswa sehingga siswa dapat memahaminya dengan lebih mudah (Busyaeri, Udin \& Zaenuddin, 2016).

Selama ini telah banyak dilakukan penelitian yang mengidentifikasi kebermanfaatan video dalam proses pembelajaran. Penelitian yang dilakukan oleh Bravo, Amante, Simo, Enache \& Fernandez (2011) menunjukkan bahwa video memberikan pengaruh positif terhadap persepsi siswa tentang peningkatan motivasi belajarnya. Video memungkinkan pengajar dapat memberikan penjelasan yang lebih cepat dibandingkan dengan bentuk lisan atau tertulis. Perlu diperhatikan bahwa video memungkinkan penayangan yang cepat dan mudah tetapi hanya menyediakan konten yang sangat spesifik. Oleh karena itu video tidak boleh dianggap sebagai elemen yang utama. Penjelasan tertulis terkait dengan konten audiovisual adalah bahan ajar yang sangat baik.

Penggunaan video memberikan kesempatan untuk melibatkan siswa dalam berpikir dan belajar tentang ide-ide sains yang mungkin tidak dapat diakses oleh mereka melalui kerja praktik dan pendekatan pedagogis lainnya. Hasil penelitian menunjukkan bahwa dari perspektif seorang guru, penggunaan video untuk menyajikan gagasan ilmiah merupakan alternatif dari bentuk pengajaran lain seperti penjelasan di buku teks atau pengajaran didaktik dengan kombinasi gambaran fenomena alam bersama penjelasan ahli menjadi pilihan yang menarik. Kemudian dari perspektif siswa mereka merasa penggunaan video dapat membangkitkan emosi yang kuat tentang manfaat relatif dari penyajian yang berbeda (Higgins, Moeed \& Eden, 2018).

Hasil yang diperoleh dari penggunaan video dapat dirasakan secara positif maupun negatif, hal ini sesuai dengan hasil penelitian Boateng, Boateng, Awuah, Ansong \& Anderson (2016). Dampak positif penggunaan video adalah memungkinkan siswa untuk mendapatkan pemahaman yang lebih baik, membantu siswa mengingat dengan mudah dan membuat belajar menjadi lebih mudah. Disisi lain, terdapat beberapa dampak negatif yang dirasakan terkait penggunaan video yaitu siswa merasa malas atau enggan terhadap video yang mereka tonton disebabkan dari isi konten, format video, ukuran video maupun durasi video. Mereka menyarankan bahwa untuk meningkatkan konten video, video harus menggambarkan perilaku manusia yang otentik. Video juga harus bersifat interaktif dan hidup. Namun sebagian siswa merasa bahwa video yang mereka tonton dapat meningkatkan hasil belajar mereka. Hal ini menunjukkan bahwa video tidak hanya pelengkap penting untuk pengajaran secara konvensional tetapi sebenarnya merupakan sarana untuk mencapai tujuan pembelajaran yang diinginkan. 
Penggunaan video memang terasa kebermanfaatannya dalam proses pembelajaran. Namun situasi pandemi Covid-19 memaksa kita untuk melaksanakan kegiatan belajar dari rumah sesuai dengan kebijakan Kementerian Pendidikan dan Kebudayaan (Fatwa, 2020). Pendidik diharuskan menggunakan metode daring untuk melanjutkan proses pembelajaran. Siswa belajar dari rumah masing-masing menggunakan aplikasi tertentu (Umairah \& Zulfah, 2020). Maka dari itu penulis memanfaatkan aplikasi Google Classroom sebagai salah satu cara untuk melaksanakan proses pembelajaran jarak jauh termasuk pemberian materi dan video pembelajaran yang berlangsung di salah satu SMA di Riau yaitu SMAN 1 Pagaran Tapah Darussalam.

SMAN 1 Pagaran Tapah Darussalam menggunakan aplikasi Google Classroom sebagai salah satu alternatif dalam pelaksanaan pembelajaran jarak jauh. Google Classroom dirancang untuk mempermudah interaksi antara guru dan siswa selama pembelajaran daring. Aplikasi ini memberikan kesempatan kepada siswa untuk mengakses kembali materi karena semuanya disimpan secara otomatis sehingga guru lebih bisa bereksplorasi (Ernawati, 2018). Google Classroom sangat berguna dalam meningkatkan kemampuan dan keterampilan siswa. Siswa dapat belajar sendiri dan melalui bimbingan, siswa dapat menemukan hal-hal baru dengan menuntut belajar secara aktif melalui Google Classroom. Namun penggunaannya dalam pembelajaran harus didukung oleh infrastruktur teknologi seperti perangkat komputer atau smartphone dan internet (Alim, Linda, Gunawan \& Saad, 2019). Selanjutnya Hapsari \& Pamungkas (2019) menyatakan bahwa Google Classroom berperan untuk memperlancar komunikasi jarak jauh antara pendidik dan peserta didik dalam proses pembelajaran. Melalui Google Classroom kita dapat memperoleh materi, mengirim tugas, hingga menyajikan penilaian tanpa harus bertatap muka secara langsung. Hal ini tentunya dapat menjadi sarana belajar bersama.

Penggunaan video dalam penelitian ini sangat membantu siswa dalam mengorganisasikan materi dengan baik. Peneliti membuat video yang diawali dengan urutan materi yang lebih mudah dipahami siswa. Video yang ditampilkan selain berisikan materi pembelajaran, juga disertai dengan penjelasan langsung dari peneliti terhadap materi tersebut dengan tampilan yang menarik. Dengan demikian, diharapkan dapat meningkatkan motivasi siswa dalam belajar biologi.

Hasil observasi awal di SMAN 1 Pagaran Tapah diketahui bahwa motivasi belajar siswa memang rendah. Hal ini dapat dilihat dari jumlah siswa yang ikut berpartisipasi dalam pelaksanaan pembelajaran jarak jauh baik yang dilaksanakan melalui WA grup, zoom, maupun Google Classroom, hanya sekitar 14 orang siswa saja yang ikut berpartisipasi dari 30 siswa yang ada. Oleh karena itu diperlukan media pembelajaran yang tepat dan dapat memicu motivasi belajar biologi siswa. Tujuan yang ingin dicapai dalam penelitian ini adalah mengetahui 
motivasi belajar biologi siswa kelas XI IPA SMAN 1 Pagaran Tapah Darussalam dengan menggunakan media berbasis video pada Google Classroom.

\section{METODE}

Penelitian ini menggunakan metode deskriptif. Teknik pengumpulan data yang digunakan adalah survei, sedangkan instrumen yang digunakan berupa angket. Data-data kuantitatif dalam penelitian ini diperoleh dengan cara menghitung skor berdasarkan jawaban angket yang diberikan siswa. Pelaksanaan penelitian berlangsung di SMA Negeri 1 Pagaran Tapah Darussalam pada semester ganjil tahun ajaran 2020/2021. Teknik pengambilan sampel menggunakan teknik sampel jenuh yaitu seluruh siswa kelas XI IPA yang mengikuti mata pelajaran Biologi. Jumlah sampel penelitian adalah 30 orang.

Prosedur pelaksanaan pada penelitian ini dimulai dari tahap persiapan. Tahap ini peneliti meminta izin pada kepala sekolah untuk melaksanakan penelitian. Tahapan berikutnya adalah penentuan sampel penelitian yaitu seluruh siswa yang ada di kelas XI IPA SMAN 1 Pagaran Tapah Darussalam. Instrumen dalam pengumpulan data berupa angket. Angket dimodifikasi dari Listiyanto (2015). Pernyataan angket terdiri atas 35 butir pernyataan dengan 4 alternatif jawaban. Indikator motivasi belajar terdiri dari ketertarikan siswa pada media yang digunakan, efektifitas media, perasaan senang, kemauan, kecerdasan, kemandirian, dorongan orang tua, peran guru, dan persaingan.

Setelah tahap persiapan, dilanjutkan dengan tahap pelaksanaan. Pada tahap ini peneliti menyebarkan angket kepada responden yang dilakukan pada bulan Oktober 2020 secara online melalui Google Form. Seluruh data yang diperoleh dilakukan pengolahan dan analisis. Data angket yang berupa skor jawaban angket dianalisis secara kuantitatif. Hasil analisis ini selanjutnya diberikan deskripsi. Perhitungan persentase motivasi siswa dihitung menggunakan rumus berikut ini (Sudijono, 2008):

$$
\mathrm{P}=\frac{\mathrm{f}}{\mathrm{n}} \times 100 \%
$$

Keterangan :

$\mathrm{P}=$ Persentase yang dicari

$f=$ Frekuensi jawaban angket

$n$ = Jumlah sampel

Untuk mengetahui motivasi belajar biologi siswa kelas XI IPA dengan menggunakan media berbasis video pada Google Classroom maka akan dilihat dengan menggunakan hasil sebagaimana yang tercantum pada Tabel 1 berikut. 
Tabel 1. Kriteria Persentase Motivasi Belajar Biologi

\begin{tabular}{ccc}
\hline No. & Interval Motivasi Belajar & Kategori \\
\hline 1. & $86 \%-100 \%$ & Sangat Tinggi \\
\hline 2. & $71 \%-85 \%$ & Tinggi \\
\hline 3. & $56 \%-70 \%$ & Cukup Tinggi \\
\hline 4. & $41 \%-55 \%$ & Rendah \\
\hline 5. & $\leq 40 \%$ & Sangat Rendah \\
\hline
\end{tabular}

(Suharini, 2021)

\section{HASIL DAN PEMBAHASAN}

Hasil

Proses pembelajaran selama masa pandemi Covid-19 di kelas XI IPA SMAN 1 Pagaran Tapah Darussalam berlangsung secara daring atau pembelajaran jarak jauh. Cara yang dilakukan guru dalam menyampaikan materi tentunya berpengaruh terhadap motivasi belajar siswa. Salah satu cara yang dilakukan adalah memanfaatkan media pembelajaran berbasis video yang penyampaiannya dilakukan melakukan Google Classroom. Pelaksanaan pembelajaran dengan menggunakan media berbasis video melalui Google Classroom dapat dilihat pada Gambar 1.
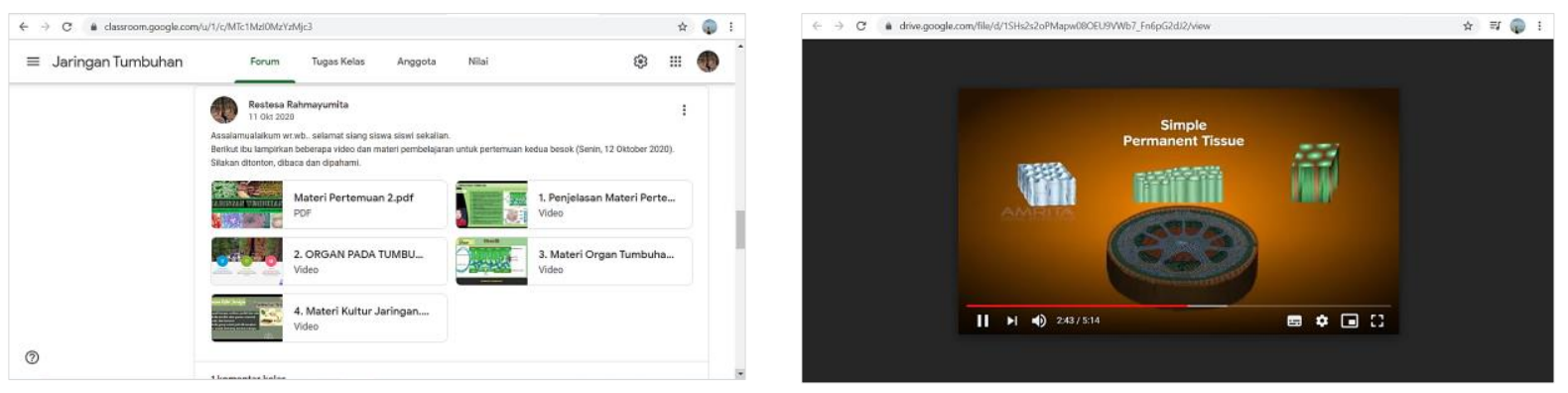

Gambar 1. Media Pembelajaran Berbasis Video yang Disampaikan Melalui Google Classroom

Siswa kelas XI IPA di SMAN 1 Pagaran Tapah telah melaksanakan proses pembelajaran dengan menggunakan video dan Google Classroom sehingga peneliti ingin melihat motivasinya. Motivasi belajar siswa dalam pembelajaran biologi dapat dilihat dari angket yang telah disebarkan. Berdasarkan penelitian yang telah dilakukan melalui penyebaran angket yang terdiri dari 9 indikator dan 35 butir pernyataan diperoleh hasil seperti yang tampak pada Tabel 2 .

Tabel 2. Hasil Analisis Data Tiap Indikator Motivasi Belajar Terhadap Penggunaan Media

\begin{tabular}{clcc}
\hline No. & \multicolumn{1}{c}{ Indikator } & Rata-rata (\%) & Kategori \\
\hline 1. & Ketertarikan siswa pada media yang digunakan & $71,67 \%$ & Tinggi \\
\hline 2. & Efektifitas media & $71,17 \%$ & Tinggi \\
\hline 3. & Perasaan senang & $84,58 \%$ & Tinggi \\
\hline 4. & Kemauan & $76,55 \%$ & Tinggi \\
\hline 5. & Kecerdasan & $77,00 \%$ & Tinggi \\
\hline 6. & Kemandirian & $73,61 \%$ & Tinggi \\
\hline
\end{tabular}




\begin{tabular}{clcc}
\hline 7. & Dorongan orang tua & $78,34 \%$ & Tinggi \\
\hline 8. & Peran guru & $72,71 \%$ & Tinggi \\
\hline 9. & Persaingan & $75,28 \%$ & Tinggi \\
\hline & Rata-rata & $75,65 \%$ & Tinggi \\
\hline
\end{tabular}

\section{Pembahasan}

Motivasi belajar siswa kelas XI IPA di SMAN 1 Pagaran Tapah Darussalam dalam pembelajaran biologi berada pada kategori tinggi dengan persentase $75,65 \%$. Motivasi tertinggi berada pada indikator perasaan senang dengan nilai 84,58\%. Indikator ini lebih tinggi dibandingkan indikator lainnya karena siswa menunjukkan rasa suka dalam kegiatan belajar biologi baik dari segi guru dan mata pelajaran. Perasaan senang dapat terjalin dari komunikasi yang baik antara guru dan siswa, penggunaan metode dan media pembelajaran yang menarik serta bervariasi. Cara-cara seperti ini dapat memicu rasa senang siswa terhadap pelajaran yang mereka pelajari (Ricardo \& Meilani, 2017) karena strategi pembelajaran aktif memiliki korelasi positif dengan tingkat kebahagiaan siswa (Omar, Jain \& Noordin, 2013).

Indikator yang paling rendah berasal dari efektifitas media meskipun tidak terlalu rendah persentasenya dibandingkan dengan indikator lainnya yaitu sebesar $71,17 \%$. Indikator ini paling rendah karena masih terdapat siswa yang mengeluhkan penggunaan video dengan alasan rendahnya konektivitas dan memakan banyak kuota internet. Penggunaan video sebagai media pembelajaran merupakan proses pengajaran yang efektif untuk meningkatkan motivasi belajar siswa karena dapat dikombinasikan dengan teknik belajar yang bervariasi sehingga dapat membuat siswa lebih semangat dalam belajar (Bravo, Amante, Simo, Enache \& Fernandez, 2011; Irwanto \& Guswiani, 2019; Kosterelioglu, 2016). Meskipun telah menggunakan video sebagai media pembelajaran, namun masih ditemukan kendala karena proses pembelajaran berlangsung secara daring. Proses pembelajaran yang dilaksanakan secara daring dinilai kurang efektif karena ada saja siswa yang beralasan bahwa tidak adanya koneksi internet atau memiliki keterbatasan kuota internet (Taradisa, Jarmita \& Emafilda, 2020). Selain itu, pembelajaran daring juga tidak selamanya dapat memfasilitasi siswa dengan kemampuan komunikasi kurang baik karena meskipun mungkin siswa memiliki pengetahuan yang sangat baik di bidang akademik, mereka mungkin tidak memiliki keterampilan yang dibutuhkan untuk menyampaikan pengetahuan yang mereka peroleh kepada orang lain (Arkorful \& Abaidoo, 2014).

Indikator ketertarikan siswa pada media yang digunakan termasuk ke dalam kategori tinggi dengan nilai 71,67\% karena video merupakan media berbasis audiovisual yang dapat mempermudah siswa dalam memahami materi. Penggunaan media sebagai alat bantu dalam proses pembelajaran dapat memicu ketertarikan siswa terhadap materi yang disampaikan (Anshor, Sugiyanta \& Utami, 2015). Dengan demikian, penggunaan video sebagai media 
pembelajaran tentunya dapat meningkatkan motivasi belajar siswa karena siswa merasa tertarik untuk mempelajari materi tersebut dengan bantuan video.

Indikator kemauan berada pada kategori tinggi dengan nilai 76,55\% karena siswa ikut serta dalam kegiatan pembelajaran yang dilaksanakan melalui Google Classroom. Menurut Moslem, Komaro \& Yayat (2019) kemauan memainkan peranan penting dalam belajar. Adanya kemauan dapat mendorong siswa untuk belajar, jika tidak ada kemauan maka akan melemahkan belajar siswa. Kemudian untuk indikator kecerdasan berada pada kategori tinggi dengan nilai $77,00 \%$. Hal ini dimungkinkan terjadi karena nilai yang diperoleh siswa dalam mengerjakan tugas-tugas sudah baik. Kecerdasan adalah modal utama dalam melaksanakan kegiatan pembelajaran untuk mencapai hasil belajar yang maksimal (Aulia, 2017) sehingga siswa yang memiliki kecerdasan tinggi pasti ia memiliki motivasi belajar yang kuat.

Indikator kemandirian berada pada kategori tinggi dengan nilai $73,61 \%$ karena siswa telah melaksanakan tugas belajar yang diberikan dengan baik. Kurniawan (2014) menyatakan bahwa tingginya motivasi belajar yang dimiliki siswa biasanya membuat ia mampu menyelesaikan tugasnya sendiri, sehingga kemandirian belajarnya cenderung tinggi. Begitupun sebaliknya, rendahnya motivasi belajar membuat siswa cenderung mengandalkan orang lain untuk membantunya mengerjakan tugas sehingga kemandirian belajarnya rendah. Namun juga perlu dipahami bahwa agar sampai pada tahap kemandirian ini, siswa membutuhkan bimbingan dan umpan balik khusus untuk memotivasi mereka (Regan, 2003). Indikator selanjutnya adalah dorongan orang tua yang berada pada kategori tinggi dengan nilai 78,34\% karena pelaksanaan pembelajaran dari rumah dalam situasi seperti saat ini membuat para orang tua mau tidak mau turut serta mendampingi anaknya dalam belajar atau minimal mampu memberikan suasana yang nyaman selama anaknya melaksanakan pembelajaran daring. Orang tua berperan dalam menumbuhkan motivasi atau rangsangan eksternal yang nantinya mampu menumbuhkan motivasi dari dalam diri anaknya secara alamiah (Pavalache-Ilie \& Țîrdia, 2015; Wahidin, 2019).

Indikator peran guru berada pada kategori tinggi dengan nilai $72,71 \%$ karena siswa mulai menunjukkan keaktifannya selama proses pembelajaran berlangsung. Guru berperan penting dalam memotivasi belajar siswa, jika guru tidak terlibat dalam motivasi belajar siswa akan menyebabkan siswa cenderung bersikap pasif (Arianti, 2018). Literatur tentang pembelajaran dan motivasi mengungkapkan bahwa guru dapat meningkatkan motivasi belajar siswa. Peran guru dalam motivasi tidak terbatas pada menciptakan lingkungan yang kondusif namun juga meningkatkan kemandirian siswa (Johnson, 2017). Kemudian indikator yang terakhir yaitu persaingan berada pada kategori tinggi dengan nilai 75,28\% karena adanya kompetisi antara siswa satu dengan yang lain dapat memicu semangat belajar sehingga dapat meningkatkan motivasi belajar. Seperti yang diungkapkan oleh Rumhadi (2017) bahwa persaingan dapat 
dijadikan sebagai alat motivasi untuk mendorong siswa giat belajar dan memicu prestasi belajarnya.

Penggunaan video sebagai media pembelajaran yang dikombinasikan dengan Google Classroom selama pembelajaran daring terbukti membantu guru ketika melaksanakan pembelajaran. Video pembelajaran yang diperlihatkan kepada siswa dapat memacu siswa untuk mengikuti pembelajaran dengan baik karena dengan adanya pemacu berupa video dapat mengarahkan siswa melakukan tindakan tertentu (Surya, 2004). Selain itu, siswa dapat mengakses video sesuai dengan waktu yang mereka miliki sehingga media yang digunakan harus mendekati siswa dari sudut yang nampaknya menarik dan relevan bagi siswa (Bravo, Amante, Simo, Enache \& Fernandez, 2011). Namun demikian guru juga perlu mempertimbangkan berbagai faktor lainnya ketika menerapkan video sebagai media pembelajaran terutama ketika pembelajaran daring. Misalnya, kesempatan belajar jarak jauh, ketersediaan perangkat pendukung, preferensi dalam format penyampaian (Huang \& Hew, 2017), pengalaman dalam menggunakan internet untuk pembelajaran (Chokri, 2012), kehadiran pendidik dalam pengaturan pembelajaran daring, interaksi antara siswa, guru dan konten, dan hubungan yang dirancang antara aktivitas daring dan luring (Nortvig, Petersen \& Balle, 2018).

\section{SIMPULAN}

Pemanfaatan video sebagai media pembelajaran dapat menggunakan Google Classroom sebagai alat bantu untuk penyampai informasi pada pembelajaran daring. Penggunaan media berbasis video sebagai media pembelajaran melalui Google Classroom efektif untuk meningkatkan motivasi belajar biologi siswa di kelas XI IPA SMAN 1 Pagaran Tapah Darussalam dengan nilai $75,65 \%$ dan berada pada kategori baik. Penelitian lanjutan dapat dilakukan dengan meminta siswa berkreasi membuat video sesuai dengan topik yang dipelajari. Video ini dapat digunakan sebagai langkah awal memotivasi siswa. Dengan kata lain, video pembelajaran tidak hanya disiapkan oleh guru namun siswa juga bisa membuatnya.

\section{REFERENSI}

Alim, N., Linda, W., Gunawan, F., \& Saad, M. S. (2019). The effectiveness of google classroom as an instructional media: a case of state islamic institute of Kendari, Indonesia. Humanities \& Social Sciences Reviews, $7(2), \quad 240-246$. https://doi.org/10.18510/hssr.2019.7227

Anshor, S., Sugiyanta, I. G., \& Utami, R. K. S. (2015). Penggunaan media pembelajaran berbasis video terhadap aktivitas dan hasil belajar geografi. Jurnal Penelitian Geografi, 3(7), $1-9$.

Arianti, A. (2018). Peranan guru dalam meningkatkan motivasi belajar siswa. Didaktika Jurnal Kependidikan, 12(2), 117-134.

Arkorful, V., \& Abaidoo, N. (2014). The role of e-learning, the advantages and disadvantages of its adoption in higher education . International Journal of Education and Research, 2(12), 397- 
410.

Aulia, F. (2017). Faktor-faktor yang mempengaruhi rendahnya motivasi belajar siswa pada mata pelajaran matematika materi trigonometri kelas XI MAN Bawu Jepara tahun ajaran 2016/2017. UIN Walisongo.

Boateng, R., Boateng, S. L., Awuah, R. B., Ansong, E., \& Anderson, A. B. (2016). Videos in learning in higher education: assessing perceptions and attitudes of students at the University of Ghana. Smart Learning Environments, 3(8), 1-13. https://doi.org/10.1186/s40561-016-0031-5

Bravo, E., Amante, B., Simo, P., Enache, M., \& Fernandez, V. (2011). Video as a new teaching tool to increase student motivation. IEEE Global Engineering Education Conference (EDUCON), 638-642. https://doi.org/10.1109/EDUCON.2011.5773205

Busyaeri, A., Udin, T., \& Zaenuddin, A. (2016). Pengaruh penggunaan video pembelajaran terhadap peningkatan hasil belajar mapel IPA di MIN Kroya Cirebon. Al Ibtida: Jurnal Pendidikan Guru MI, 3(1), 116-137.

Chokri, B. (2012). Factors influencing the adoption of the e- learning technology in teaching and learning by students of a university class. European Scientific Journal, 8(28), 165-190.

Emda, A. (2017). Kedudukan motivasi belajar siswa dalam pembelajaran. Lantanida Journal, $5(2), 172-182$.

Ernawati. (2018). Pengaruh penggunaan aplikasi google classroom terhadap kualitas pembelajaran dan hasil belajar siswa pada mata pelajaran ekonomi kelas XI di MAN 1 kota Tangerang Selatan. UIN Syarif Hidayatullah.

Fatwa, A. (2020). Pemanfaatan teknologi pendidikan di era new normal. Indonesian Journal of Instructional, 1(2), 20-30.

Hapsari, S. A., \& Pamungkas, H. (2019). Pemanfaatan google classroom sebagai media pembelajaran online di Universitas Dian Nuswantoro. WACANA: Jurnal Ilmiah Ilmu Komunikasi, 18(2), 225-233. https://doi.org/10.32509/wacana.v18i2.924

Higgins, J., Moeed, A., \& Eden, R. (2018). Video as a mediating artefact of science learning: cogenerated views of what helps students learn from watching video. Asia-Pacific Science Education, 4(6), 1-19. https://doi.org/10.1186/s41029-018-0022-7

Houwer, J. De, Barnes-Holmes, D., \& Moors, A. (2013). What is learning? On the nature and merits of a functional definition of learning. Psychonomic Bulletin \& Review, 20(4), 631-642. https://doi.org/10.3758/s13423-013-0386-3

Huang, B., \& Hew, K. F. (2017). Factors influencing learning and factors influencing persistence: a mixed-method study of MOOC learners' motivation. Proceedings of the 2017 International Conference on Information System and Data Mining, 103-110. https://doi.org/10.1145/3077584.3077610

Irwanto, \& Guswiani, W. (2019). Efektivitas penggunaan video pembelajaran dalam meningkatkan motivasi dan hasil belajar siswa dalam pembelajaran front office di kelas XI akomodasi perhotelan SMK N 3 Garut. LITERASI (Jurnal Ilmu Pendidikan), 10(2), 77-91.

Johnson, D. (2017). The role of teachers in motivating students to learn. BU Journal of Graduate Studies in Education, 9(1), 46-49.

Kosterelioglu, I. (2016). Student views on learning environments enriched by video clips. Universal Journal of Educational Research, 4(2), 359-369. https://doi.org/10.13189/ujer.2016.040207

Kurniawan, D. (2014). Kemandirian, hubungan motivasi belajar terhadap studi, belajar siswa kelas XI pada kompetensi mengidentifikasi sistem pengapian dan komponennya program keahlian teknik otomotif SMK Tamansiswa Yogyakarta tahun ajaran 2013/2014. Universitas Negeri 
Yogyakarta.

Listiyanto, T. (2015). Pengaruh pemanfaatan video edukasi sebagai media pembelajaran terhadap motivasi belajar sejarah siswa kelas XI IPS di SMA Negeri 1 Bandar tahun ajaran 2014/2015. Universitas Negeri Semarang.

Lubis, M. S. (2016). Diktat Teori Belajar dan Pembelajaran Matematika. UIN Sumatera Utara.

Moslem, M. C., Komaro, M., \& Yayat. (2019). Faktor-faktor yang menyebabkan rendahnya motivasi belajar siswa dalam mata pelajaran aircraft drawing di SMK. Journal of Mechanical Engineering Education, 6(2), 258-265.

Nafisah, D. (2011). Identifikasi kesulitan belajar ipa biologi siswa kelas IX SMP Negeri 5 Ungaran. Universitas Negeri Semarang.

Nortvig, A., Petersen, A. K., \& Balle, S. H. (2018). A literature review of the factors influencing e-learning and blended learning in relation to learning outcome, student satisfaction and engagement. Electronic Journal of E-Learning, 16(1), 46-55.

Omar, S., Jain, J., \& Noordin, F. (2013). Motivation in learning and happiness among the low science achievers of a polytechnic institution: an exploratory study. Procedia - Social and Behavioral Sciences, 90, 702-711. https://doi.org/10.1016/j.sbspro.2013.07.143

Pavalache-Ilie, M., \& Țîrdia, F.-A. (2015). Parental involvement and intrinsic motivation with primary school students. Procedia-Social and Behavioral Sciences, 187, 607-612. https://doi.org/10.1016/j.sbspro.2015.03.113

Qvortrup, A., Wiberg, M., Christensen, G., \& Hansbøl, M. (2016). On the definition of learning. University Press of Southern Denmark.

Regan, J. A. (2003). Motivating students towards self-directed learning. Nurse Education Today, 23(8), 593-599. https:// doi.org/10.1016/S0260-6917(03)00099-6

Ricardo, \& Meilani, R. I. (2017). Impak minat dan motivasi belajar terhadap hasil belajar siswa (The impacts of students' learning interest and motivation on their learning outcomes). Jurnal Pendidikan Manajemen Perkantoran (JPManper), 2(2), 188-201.

Rumhadi, T. (2017). Urgensi motivasi dalam proses pembelajaran (The urgent of motivation in learning process). Jurnal Diktat Keagamaan, 11(1), 33-41.

Saptono, Y. J. (2016). Motivasi dan keberhasilan belajar siswa. REGULA FIDEI: Jurnal Pendidikan Agama Kristen, 1(1), 189-212.

Schunk, D. H. (2012). Learning theories: an educational perspective (Sixth Edit). Pearson.

Simorangkir, A., \& Napitupulu, M. A. (2020). Analisis kesulitan belajar siswa pada materi sistem ekskresi manusia. Jurnal Pelita Pendidikan, 8(1), 1-11.

Sudijono, A. (2008). Pengantar statistik pendidikan. Raja Grafindo Persada.

Suharini, D., E., Sri. (2021). Peningkatan Motivasi Belajar Peserta Didik melalui Pendekatan Bimbingan Kelompok. Jurnal Kreatif Online, 9(3), 90-98.

Surya, M. (2004). Psikologi pembelajaran dan pengajaran. Pusaka Bani Quraisy.

Syahbani, Y., Haris, A., \& Palloan, P. (2019). Persepsi siswa tentang media pembelajaran power point dalam pembelajaran fisika pada peserta didik kelas XI MIA 2 SMA Negeri 9 Makassar. Jurnal Sains dan Pendidikan Fisika, 15(2), 18-22.

Taradisa, N., Jarmita, N., \& Emafilda. (2020). Kendala yang dihadapi guru mengajar daring pada masa pandemi covid-19 di MIN 5 Banda Aceh. 1-11.

Tsai, C.-H., Cheng, C.-H., Yeh, D.-Y., \& Lin, S.-Y. (2016). Can learning motivation predict learning achievement? A case study of a mobile game-based english learning approach. Education and Information Technologies, 22(5), 2159-2173. https://doi.org/10.1007/s10639016-9542-5

Umairah, P., \& Zulfah. (2020). Peningkatan motivasi belajar menggunakan "google classroom" 
ditengah pandemi covid-19 pada peserta didik kelas XI IPS 4 SMAN 1 Bangkinang Kota. Journal on Education, 2(3), 275-285.

Wahidin. (2019). Peran orang tua dalam menumbuhkan motivasi belajar pada anak sekolah dasar. JURNAL PANCAR (Pendidik Anak Cerdas dan Pintar), 3(1), 232-245. 